\title{
Resourceson the Net
}

\author{
Workplace Information Literacy \\ Compiled by Chris Bober
}

\section{Research Reports}

Ali, R., \& Katz, I. (2010, August). Information and communication technology literacy: What do businesses expect and what do business schools teach? (ETS RR-10-17). Retrieved from Educational Testing Service website: $\underline{\text { http://www.ets.org/Media/Research/pdf/RR-10-17.pdf }}$

One of the recent trends reported in the literature on the $21^{\text {st }}$ century workplace is the convergence of information literacy and technology literacy, or ICT literacy. ICT literacy includes seven key performance areas: "defining a need for information, accessing information via technology, evaluating online information, managing digital information, integrating information from varied digital sources, creating information, and communicating information through technology." The authors report on two qualitative studies that used questionnaires which were sent to human resources consultants and to business faculty to measure the extent to which these skills were valued by employers and taught in business schools. Findings indicated that while employers highly value ICT literacy skills, students were not entering the labor force with these skills as they were not being integrated into the business school curriculum.

\section{Conference Papers}

Kirk, J. (2004). Information and work: Extending the roles of information professionals. Paper presented at the Australian Library and Information Association 2004 Biennial Conference. Retrieved from http://conferences.alia.org.au/alia2004/pdfs/kirk.j.paper.pdf

This paper reports on a research study on fifteen senior managers from two public sector organizations. The study identified five different experiences of information use. It was discovered that information use was not an individual activity, but was embedded in complex social relationships within the workplace. The process of developing new knowledge "is often a highly social one that relies on the exchange of information and interaction with trusted others." The study also explored the unique opportunities for extending the roles of information professionals on the use of information in the workplace: "by attending to the informational, organizational and personal elements that shape information use there remains the prospect of offering personalized information services to senior managers that will benefit the organization."

\section{Peer Reviewed Journal Articles}

Cheuk, B. (2008, September). Delivering business value through information literacy in the workplace. Libri, 58(3), 137-143. Retrieved from http://www.librijournal.org/pdf/2008-3pp137-143.pdf

This paper presents a case study of how a large multinational environmental consulting firm integrated information literacy on a limited scale into its newly created knowledge management training program. This training program was developed partly to address the problem of information overload in the workplace. A 'global knowledge sharing team' was established, consisting of four information professionals. Their first task was to explore the "range of existing and potential information problems that employees experience at work..." The team adapted their information literacy strategy from Bruce's seven faces of information literacy and came up with a scaled down version that targeted senior managers and consultants. It was 
successful on this limited scale but the author acknowledged that much work needed to be done in order to provide more than basic training to all staff in the organization.

Hadley, S., \& Hacker, K. (2007). Embedding information literacy into staff development in an acute National Health Service (NHS) trust. Journal of Information Literacy, 1(2). Retrieved from http://jil.lboro.ac.uk/ojs/index.php/JIL/article/view/AFP-V1-I2-2007-3/15

Hadley and Hacker describe the evolution of a course that integrated some components of information literacy skill development into a program that was designed for healthcare personnel, specifically nurses and support staff. When first launched, it featured "a mixture of taught sessions, group discussions, individual tutorials and hands on literature practice." Based on experience and feedback, the course was later restructured to include a more learner centered approach. It was later found that the needs of individual learners were not being met. It was recommended that future iterations of the course should include a series of integrated modules which learners could select according to their individual needs, and also feature opportunities for e-learning to allow for more self directed learning.

Kirton, J., \& Barham, L. (2005, November). Information literacy in the workplace. The Australian Library Journal, 54(4). 365-376. Retrieved from http://www.alia.org.au/publishing/alj/54.4/alj.Vol_54_No_04_2005.pdf\#page=41

This literature review focuses on recent research and studies relevant to information literacy in the workplace. The authors report that very little to date has been published about the role and value that information literacy has in the workplace, and even less about the contributions of special libraries in this process. The authors conclude that the "growth and importance of information and communications technologies and resources, coupled with the need for staff to be information literate, provides a unique opportunity for special librarians to prove their value by playing a greater role in their organizations."

Lloyd, A. (2007). Recasting information literacy as sociocultural practice: Implications for library and information science researchers. Information Research, 12(4). Retrieved from http://informationr.net/ir/12-4/colis/colis34.html

Lloyd proposes a radical shift in library and information research on workplace information literacy away from skills based literacy towards a more holistic model that examines the sociocultural outcomes of engaging with information. Two qualitative interview based studies were conducted on nonprofessional emergency response team members and their use of information in training and in practice environments. The complex process of how novice learners in training transition into practitioners is profiled through their engagement with information, where they "are drawn away from the artificial constructs of practice constructed in preparatory training, towards collective stories and workplace practices which reflect the realities of actual work."

Somerville, M.M., \& Howard, Z. (2008, August). Systems thinking: An approach for advancing workplace information literacy. The Australian Library Journal, 57(3), 257-273. Retrieved from http://alia.org.au/publishing/alj/57/ALJ_Vol57_No3 2008.pdf\#page=55

This is a report of a three year case study on developing workplace information literacy competencies amongst library professionals at California Polytechnic State University. A systems thinking approach was used to build on previous research on the contribution of workplace socialization processes (collective experiences) in creating an organizational learning environment. The study adds further credence to moving 
the focus away from the individual experience, as information literacy "develops within a workplace context and is collectively experienced at both group and organizational levels."

\section{Web Sites}

Centre for education and work. (2011). Retrieved from Centre for Education and Work website: http://www.cewca.org/

The Centre for Education and Work (CEW) is a non-profit organization based in Winnipeg, Manitoba, whose stated mission is to "create, innovate and commit to developing products and services for workplace learning and adult learners." This site includes the Workplace Essential Skills Learning Assessment Tool (WESLAT), a free application that can be used to assess the state of learning in organizations. Recent CEW projects include collaborating with "researchers across Canada to observe and document six learning organizations."

International Federation of Library Associations and Institutions, Information Literacy Section. Information literacy international resources directory. (n.d.) Retrieved from http://www.infolitglobal.info/directory/en/home

This directory was created by the Information Literacy Section of the International Federation of Library Association and Institutions ( IFLA), on behalf of UNESCO. Updated regularly, it acts as a repository of information literacy materials from diverse parts of the world. The browsable database is divided into five main subject areas: products for users, publications, organizations, training the trainers, and communication.

Chartered Institute of Library and Information Professionals (CILIP). Journal of information literacy. (2010). Retrieved from Loughborough University Library Open Journals website: http://ojs.lboro.ac.uk/ojs/index.php/JIL/index

The Journal of Information Literacy "is an international, peer-reviewed, academic journal that aims to investigate Information Literacy (IL) within a wide range of settings." It is a useful source for current awareness of information literacy in the workplace Produced semi-annually, it is an open access publication with searchable archives going back to its inaugural issue in 2007. It is indexed in H.W. Wilson's Library Literature \& Information Science Full Text and in EBSCO's Library, Information Science \& Technology Abstracts (LISTA).

National Adult Literacy Database. (2011). NALD@Work. Retrieved from National Adult Literacy Database website: http://www.naldatwork.ca/

Canada's National Adult Literacy Database (NALD), founded in 1989, is a digital library whose mission is to provide literacy and essential skills information and resources. NALD@Work, an offshoot of NALD, was launched in 2007 to include workplace literacy information. Available resources include "research and learning materials; news items; a calendar of events; and links to workplace-related contacts, websites and tools.” NALD@Work can also be used to develop workplace education programs.

National Forum on Information Literacy. (2011). $21^{\text {st }}$ century skills. Retrieved from National Forum on Information Literacy website: http://infolit.org/

The National Forum on Information Literacy is a U.S. based network of over 93 agencies that support the development of information literacy skills in schools, in the workplace, and in everyday life. This site contains links to news and current projects in the field, as well as links to their Data Center, which contains 
major "reports and data on the evolution and current status of information literacy in the United States and around the world."

Proliteracy. (2008). Retrieved from Proliteracy website:

http://www.proliteracy.org/NetCommunity/Page.aspx?pid=953

Proliteracy, an adult literacy advocacy group, is cosponsoring, along with the National Forum on Information Literacy, the inaugural U.S. Conference on Adult Literacy (USCAL) which will be held in Houston, Texas, from November 2-5, 2011. The conference will provide "professional development and training opportunities for programs and providers from adult literacy and education, family literacy, workforce development, library, corrections, and social service organizations, in order to expand and improve services." Look to this site for updates on the USCAL conference program.

\section{Blogs}

Cheuk, B. (2011). Dr. Bonnie Cheuk. Retrieved from http://bonniecheuk.blogspot.com/

Dr. Bonnie Cheuk, the blog's moderator, has published extensively in the field of workplace information literacy and knowledge management, more specifically 'knowledge sharing'. This blog, launched in 2009, features information literacy in the workplace as one of the main areas of interest.

Webber, S. (2011). Information literacy weblog. Retrieved from http://information- literacy.blogspot.com/

The Information Literacy Weblog is moderated by Ms. Sheila Webber, a faculty member in the Information School, University of Sheffield, United Kingdom, and Director of the Centre for Information Literacy Research. The blog, launched in 2008, provides current awareness of information literacy issues and initiatives from around the world, including a number of useful links to workplace information projects, primarily in the United Kingdom.

Compiler's note: Text that is enclosed within quotations marks has been taken directly from the source document.

Chris Bober is the Education Librarian at Concordia University Libraries.

Email: boberc@alcor.concordia.ca 